Louisiana State University

LSU Digital Commons

1963

\title{
Light and Electron Microscopy of the Islets of Langerhans of the Saimiri Monkey Pancreas.
}

William Burt Winborn

Louisiana State University and Agricultural \& Mechanical College

Follow this and additional works at: https://digitalcommons.Isu.edu/gradschool_disstheses

\section{Recommended Citation}

Winborn, William Burt, "Light and Electron Microscopy of the Islets of Langerhans of the Saimiri Monkey Pancreas." (1963). LSU Historical Dissertations and Theses. 864.

https://digitalcommons.Isu.edu/gradschool_disstheses/864

This Dissertation is brought to you for free and open access by the Graduate School at LSU Digital Commons. It has been accepted for inclusion in LSU Historical Dissertations and Theses by an authorized administrator of LSU Digital Commons. For more information, please contact gradetd@lsu.edu. 
This dissertation has been 64-167 microfilmed exactly as received

WINBORN, William Burt, 1931-

LIGHT AND ELECTRON MICROSCOPY OF THE ISLETS OF LANGERHANS OF THE SAIMIRI MONKEY PANCREAS.

Louisiana State University, Ph.D., 1963

Anatomy

University Microfilms, Inc., Ann Ārbor, Michigan 


\title{
LIGHT AND ELECTRON MICROSCOPY OF THE ISLETS OF LANGERHANS \\ OF 'PHE SAIMIRI MONKEY PANCREAS
}

\author{
A Dissertation \\ Submitted to the Graduate Faculty of the \\ Loulsiana State UnIversity and \\ Agricultural and Mechanical College \\ in partial fulfillment of the \\ requirements for the degree of \\ Doctor of Philosophy \\ in
}

The Department of Anatomy

$$
\text { by }
$$

William Burt Winborn

B. S., UnIversity of Texas, 1956 June, 1963 


\section{ACKONOWLEDGEMENT}

This investigation was performed under the supervision of Dr. Frank N. Low, Professor of Anatomy at the Loulsiana State University School of Medicine. The author wishes to express his sincere gratitude and appreciation to $\mathrm{Dr}$. Low for his invaluable assibtance, direction and the many bours be devoted in guiding the research and organlzation of the paper. 


\section{TABLE OF CONTENTS}

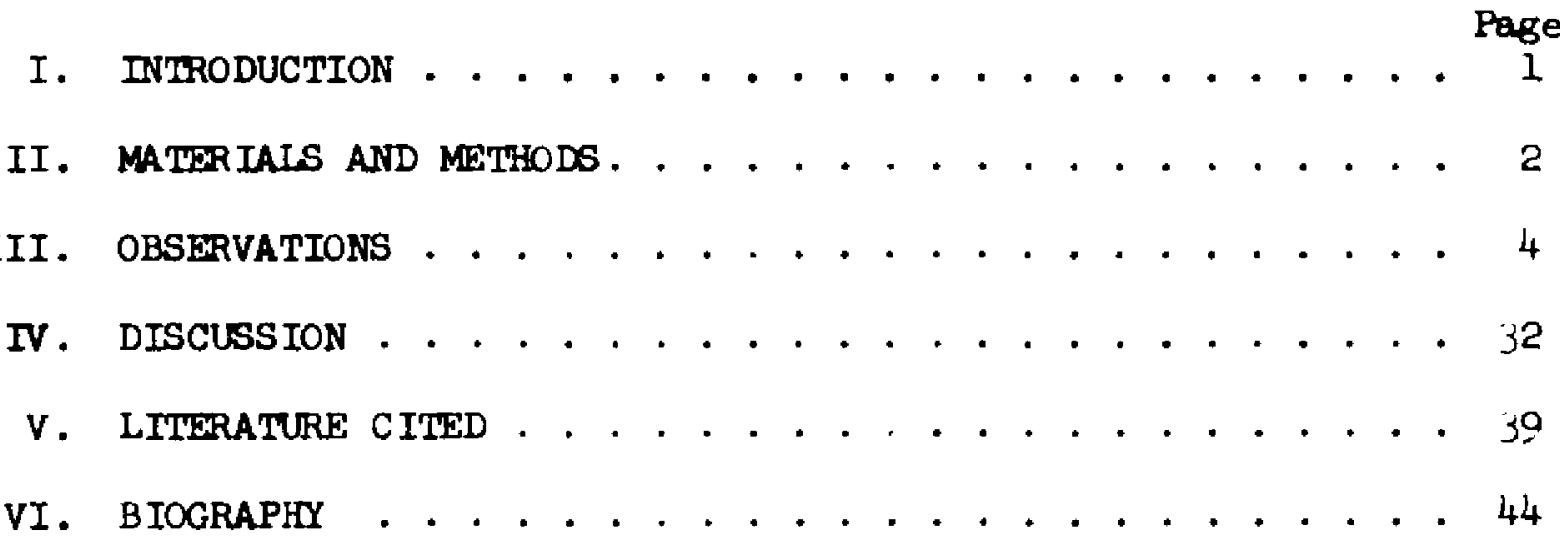




\section{LIST OF ILLUSTRATIONS}

I. Light micrographs of islets Page

II. Alpha and beta cells. . . . . . . . . . . . . . . . 15

III. Alpha, beta and intergrade cells. . . . . . . . . . . . . 17

IV. Cytology of beta cells. . . . . . . . . . . . . . . . . . 19

V. Mitochondria of alphe and beta cells. . . . . . . . . . 21

VI. Cap1llary, delta cells. . . . . . . . . . . . . . . . 23

VII. Isolated islet cells. . . . . . . . . . . . . . . . . 25

VIII. Golgi apparatus, mitochondria of duct and acinar cells. . . 27

IX. Duct cell cytology. . . . . . . . . . . . . . . . . . . 29

X. Nerve processes . . . . . . . . . . . . . . . . . . 31 


\begin{abstract}
The distribution of alpha, beta, and other 1slet cells in the tail of the pancreas of the Central American monkey (Salmiri sciurea) revealed by the light and electron microscopes, 1s similar to that occurring in man. Differentiation of acinar, islet and duct cells is based on the presence or absence of specific granules and the special morphology of the cytoplasm and 1ts membrane systems. Consplcuous lipld droplets appear in the islets, largely confined to beta and delta cells. An "Intergrade" cell is present, possessing features of both alpha and beta cells, as well as a non-granular variety of delta cells. Nerve processes which display symaptic vesicles and clusters of mitochondris are present within the islets. Islet and acinar cells are sometimes separated by connective tissue or a reticulum, as observed in light microscopy, but there may be simple apposition of their respective plasma membranes. The fine structure of this reticulum presents several levels of organization. Duct cells possess lipid masses similar to those in islet cells. These duct cells, unlike islet cells, are agranular and possess microvilli and cytoplasmic blebs, both of which show Internal structures.
\end{abstract}




\section{TNTRODUCTION}

The islets of Langerinans were first reported in electron microscopy by Dalton (151) and later by Robertson ( 54 ). Lacy (157a, b) differentiated the specific cell types and anslyzed fine structure in the guinea $1 \mathrm{~g}$, rat, rabbit and dog 1slet cells. Ferreira (157) described beta cells in embryonic and new born rats and showed specific granules in the Goloi apparatus. Experimental work was reported by W1lliamson and Lacy ('59) who injected alloxan into rabbits and observed degranulation changes in beta cells. Lacy and Hartroft (159) described three experimental results; (1) glycogen accumulation in beta cells of cats following injections of glucose, (2) changes in alpha cells induced by cobalt chloride and (3) degranulation of beta cells following orinase treatment. Normal and neoplastic beta cells in human tissue have also been described (lacy and Williamson, '60; Bencosme et al., 163). A mode of granule secretion under experimental conditions from beta cells has been postulated by Lacy ('61).

The improved image quality provided by themostable embedments (Ryter and Kellenberger, 158; Low and Clevenger, '62; Freeman and Spurlock, '62) suggested that further descriptive work on a different animal would be profitable. The Central American monkey (Saimir1 sciurea) was chosen because the 1slet tissue of this form had not been described in either light or electron microscopy. 


\section{MATERIALS AND METHODS}

Five Central American squirrel monkeys were anesthet1zed $w$ ith nembutal and the tall of each pancreas was removed. The tissue was cut into blocks not exceeding one millimeter in any dimension. These were immediately immersed in buffered osmium tetroxide (Palade, '52) or potassium permanganate (Luft, 156). Fixation was carried out for two to three hours at $0-3^{\circ}$ Centigrade. All tissues vere dehydrated in acetone and then embedded in Vestopal-W (Ryter and Kellenberger, '58), Selectron-methacrylate (Low and Clevenger, 162) or Maraglas (Freeman and Spurlock, '62). Vestopal-W embedments were initiated with t-butyl perbenzoste $^{l}$ and activated with cobalt naphthenate ${ }^{2}$ (Ryter and Kellenberger, 158). This catalyzing procedure, when used for osmiumfixed Selectron-methacrylate embedments, mads unnecessary the postfixation in neutral formalin recommended by Low and clevenger ('62). Triallyl cyanurate 3 in $10 \%$ concentration with Vestopal-W improved both the sectioning quality of the blocks and image contrast in the mounted sections. Sections were cut on the Porter-Blum and $\mathrm{KKB}$ microtomes .

Iertlary butyl perbenzoete; Wallace and Tiernan Inc., Lucidol Division, Buffalo, New York.

2 cobalt naphthenate; Heyden Newport Chemical Corp., Nuodex Products Co., Ellzabeth, New Jersey.

3Eriallyl cyanurate 18 a compound used in heat-resistant polyester resins. A sample was kindly supplied to this laboratory by Mr. H. J. Kest, Technical Coordinator, Anerican Cyanamid Co., Plastic and Resin Div., Wallingford, Conn. It is commercially avaliable in small quantities. 
Polyester sections were stained with $0.1 \%$ PTA in equal parts of acetone and ether (Low, $61 \mathrm{~b}$ ) and Maraglas sections were stained in aqueous lead hydroxide (Millonig, '61).

Formalin-fixed tissue embedded in paraffin was stained with aldehyde fuchsin (Gomor1, 150) and phloxine (Gomor1 '39) for use in light microscopy. Thick Maraglas sections for light microscopy were stained with aqueous toluidine blue (Spurlock et al., '63). 


\section{OBSERVATIONS}

A preliminary examination was made with the light microscope. Aldehyde fuchsin (Gomorl, '50) stains beta cells deep purple, positive areas appearling dark in flgures 1 and 2 . These beta cells usually represent from 60 to $30 \%$ of the total islet cell population. Phloxine (Gomor1, '39) stains the alpha and other 1slet cells pink and these appear pale in figures 1 and 2. Electron mlcroscopy shows that the pale groups are composed mostly of alpha cells and a small number of non-granulated delta cells, as reported in the cat (Bencosme and Pease, ' 58 ).

Previous electron microscopic observations of islets of several experimental animals (Lacy, '57a, b; Bencosme and Pease, '58) makes Fossible positive identificstion of specific cell types whenever entire islets are not visible. The nuclear chromatin of lolet cells is usually evenly distributed throughout the karyoplasm (figs. 3, 6, 7) but is occasionally concentrated in the perlphery of the nucleus. The nucleoll are much less conspicuous than those of acinar cells. The two components of the nuclear membrane are frequently separated, suggesting a perinuclear clstern ( $f i B .7$ ) rather than a double membrane. Continulty of the outer layer of the nuclear membrane with the cytoplasmic membranes (Watson '55) sometimes occurs in the lolet cells (fig. 7). These nuclel are irregular in outline and often appear lobulated (figs. 6, 7), as contrasted with the round and oval nuclei of duct and acinar cells. 
The cytoplasmic matrix of alpha cells is of low density (fig. 3 ). Mitochondria and specific granules characteristically stand out in sharp contrast against this background (f1gs. 3, 4, 8). Beta cells possess a matrix of higher density (figs. 3, 7, 9). The structures responsible for this are the granular and agranular endoplasmic reticulum, ribosomes and what appears to be the 1rregular tubulo-membranous component (ITM) described by Battig and Low ('Gl). All of these fine structures are in general poorly defined in alpha cells and more highly developed in beta cells. In both cell types ribosomes are scattered singly or, more often, are aggregated in clusters (fig. 8). The beta cells appear to have the higher concentration. Cytoplasmic protuberances of islet cells invaginate adjacent acinar cells as well as other Islet cells (fig. 7 ).

The mitochondria of alpha cells ( $1 \mathrm{~g} .8$ ) are fewer and more elongated than those of beta cells. Beta cell mitochondria are round, oval and somewhat irregularly shaped (flg. 9). Islet cell mitochondria possess, at high magnification, small areas of discontinuity in their outer membrane that give the Impression of "pores" (fIg. $\gamma$ ).

sections passing through or near the center of beta and delta cells almost invariably contain lipid droplets (f1gs. 3, 7, 11, 12). They are rarely seen in alpha cells. Often 86 many as three lipid masses are present in a single section of one cell. These lipid masses are usually circular in outline but oval forms are not uncommon. Each mass is surrounded by a limiting membrane (figs. $7,11,12$ ) which is denser than the lipid itself. The size of the droplets appear to be unfform within a single cell but varies from cell to cell. These droplets may exhibit circular osmiophoblc areas (fig. 12). The granular 
endoplasmlc reticulum is more prominent in the beta cells than in the alpha cells. However, neither of the two cell types possess the extensive development typical of acinar cells (fig. 16). This membrane system may appear as multiple pairs of parallel membranes (fig. 6 ) bounding very narrow cavities, but it may form short channels, lsolated and Irregularly dilated, whose membranes are randomly studded with rlbosomes (fig. 7). Tue clsternae themselves appear empty. The granular reticulum is best demonstrated where the specific granules are less densely concentrated. The agranular reticulum of alpha cells lacks the extensive definition seen in the beta cells. Here, it consists of narrow tubules or sacs, the caliber of which is more uniform than its granular counterpart.

The most conspicuous structures in the alpha cells are their specific granules. These intensely osmiophilic, homogeneous spheres appear to be morphologically identical with those already described in other animals (Lacy, '57a, b; Bencosme and Pease, '58). Each granule is surrounded by a membranous aac with a distinct intervening space between granule and membrane (figs. 4, 10, 13, 14). The granule may lie in an eccentric or concentric position within the sac. Alpha granules are about $200 \hat{A}^{\circ}$ in diameter. These granules are uniform in size except when associated with the Golg1 apparatus, where many small ones are found (eigs. 3, 14). This interpretation in a single section is based upon the observation that a granule appears most dense when the section passes through or near the center of the granule. A mature granule of comparable size (figs. 4, 8), cut tangentially, is much less dense. 
The membranes forming the sacs about the specific granules are devold of ribosomes and appear much like those forming the vesicular portion of the Golg1 apparatus (figs. 4, 14). Most often this membrane limits a single granule but two and rarely three have been observed (fig. 10). Alpha cell granules frequently occur in high concentration in the vascular pole of the cell (fig. 3).

The speciflc granules of the beta cell differ considerably from those of the alpha cells. They display a lower density and the substance of the mature granule is finely particulate (fig. 5). An "internal porous structure" (Lacy, '6l) is demonstrable in these granWles at high magnification (fig. 9). Like the alpha cell, the beta cell granule is surrounded by a membranous sac which is usually obscure (fig. 5). This is because the mature granule occuples the entire space enclosed by the membrane. Immature beta cell granules display a dense amorphous structure that does not completely fill the enclosing sac (fig. 9). They may be observed in the vesicular position of the Golgi apparatus, but are also present in other parts of the beta cell. A non-granular varlety of delta cells (Bencosme and Pease, 158) is occasionally observed in the 1slets ( $\mathrm{flg}$. 11). It is similar in appearance to the beta cells, save for the specific granules. Th1s cell type does not possess electron dense structures such as those visual.1zed as granules in alpha and beta cells. They do, however, possess comparable membranous sacs similar to those seen surrounding specific granules in alphe and beta cells. No masses are visible within the sacs of these cells. 
Material embedded in Vestopal-W often shows cells with both dense homogeneous and finely particulate granules (f1g. 6 ). This type has been arbitrarily categorized as an "intergrade" cell (Winborn, '02). Single or isolated lolet cells are present, being completely surI.sunded by acinar cells (t'igs, 12, 13). These cells are apparently not in proxlmity to larger 1slet masses. Both alpha and beta cells exhlbit this variation in cell arrangement. Beta cells have occastonally been observed formine portions of small duct systems. This identiflcation is based on the presence of specific granules in the islet cell cytoplasm.

I'ne Golgi apparatus appears to be similar in all islet cell types. It is not noticeably more prominent in one cell type than in another. This structure consists of parallel membranes, plled one upon another, numerous vesicles and irregular sacs or vacuoles (figs. $3,9,14$ ). Immature forms of granules in both alpha and beta cells are present in the saccular portion of the Gulei apparatis.

Cell.s of small intralobular and intercalated ducts, like islet cells, show lipid masses ( $11 E \cdot 17$ ). These stuuctures, however, do not appear in every cell section as is usually true with beta cells. Thick Maraglas sections stalned with Toluidine blue for light microscopy demonstrate these masses well. The duct cells, unlike the 1slets, lack specific Eranules but often possess cytoplasmic blebs and microvilli (fig. 17). Cross sections (fig. 19) of the microvilli sometimes demonstrate seven marglnally placed annull and a single central one. Longltudinal and slightly diagonal sections suggest that these annul1 represent small internal tubules or cylinders (fig. 18). Microvilli are occasionally observed with internal structures below the free 
surface of the cell (fig. 18). The basal portion of this internal structure may extend into the region of the Golg1 apparatus. The marelnal limits of the internal organization appear to be associated with intracellular fine fllaments (fig. 18). These fine fllaments in turn converge on terminal bars, thus forming a terminal web (fie. 18). The duct cell in addition possesses cytoplasmic blebs which project from the free surface of the cell. These blebs also display internal structures (figs. 17, 18). Interdigitoting processes of adjacent duct cells are present (fig. 17).

Boundaries between 1slet and acinar cells vary conslderably. The simplest boundary situation is direct apposition of the cell membranes of islet and acinar sells (flgs. 12, 13). Th1s arrangement may be modifled in the form of reciprocal interlocking processes from adjacent cells. However, direct apposition is more common and often the acinar and islet cell membranes appear as one. Separation of the two membranes by an appreciable space is made apparent by slender and extremely elongated cytoplasmic processes of fibroblasts or fingerlike processes from adjacent acinar cells. Boundary (basement) membranes (Low, 'Sla) are closely applied to both islet and acinar cell membranes when a tissue space between these two cells is evident (flgs. 3,7). Unit fibers of collagen and fibroblasts are occasionally seen in the space between the two boundary membranes.

The islet cells are richly supplied with capillaries (f1g. 10$)$. Spectfic granules display a vascular polarity in both alpha and beta cells (figs. 3, 10). The pericaplllary space or tissue space is also bounded by two boundary membranes (figs. 3, 10). One is Inmediately adjacent to the endothelial cell and the other directly applied to the 
parenchymal islet cells. Fibroblasts and unit fibers of collagen may occasionally lie in the compartment part of the tissue space formed by the two boundary membranes. The endothelium of the capillary wall is attenuated to form fenestrations (Farquhar, '6e) which are bridged by diaphragms (figs, 3) similar to those described by Rhodin ( 12 ). Golgl membranes are limited to areas near the nucleus of the endothelial cell. The granular reticulum, ribosomes, and vesicles are usually present where the fenestrations are not prominent. iere also the granular reticulum is continuous with the perinuclear cieternac of the endothelial cell.

Nerve processes are observed frcquently within islets. Most often they are typical ones without cytoplasmlc specializations. Several cases, however, revealed nerve ribers with clusters of mitochondria and symaptic vesicles. One particular area was examined in serial sections. This revealed a nerve process with numerous synaptic vesicles and clusters of mitochondrla (figs. 20, 21, 22). An encircling cell (fics. 20, 21, 22) was observed about the synapt1c process. It possessed elongated cytoplasmic extensions which came into intimate contact with a beta cell. This encircling cell possessed an elongated and large mitochondrion (fig. 22) immediately adjacent to the beta cell membrane. 


\section{IILUSTRATIONS}

\section{Explanation of plates}

All electron micrographs are from tissue fixed in $\mathrm{OBO}_{4}$. A brief explanation of figures precedes each 1llustration.

Legends for all plates
A, alpha cell
I, Intergrade cell
AC, acinar cells
$\mathrm{MM}$, intermembranous space
AR, agranular endoplasmic reticulum
IP, interdigltating process
B, beta cell
L, lipid droplet
$\mathrm{BM}$, boundary membrane
LS, longltudinal striations
CB, cytoplasmic bleb
M, mitocbondria
D, delta cell
$N$, nerve process
DE, desmosome
$\mathrm{N}_{1}$, nerve process ${ }_{1}$
E, encircling cell
$\mathrm{N}_{2}$, nerve process
EN, endothelial cell
NU, nucleus
F, fibroblast
P, protuberance
$\mathrm{FE}$, fenestrations
PO, pore
FI, cytoplasmic fllaments
R, ribosome
G, Granules
S, membranous sac
GA, Gol81 epparatus
$T$, t18 sue space
GR, granular endoplasmic reticulum
$U$, unmyelinated nerve

Z, zymogen granule 
PIATE I.

EXPLANATION OF FIGURES

The center of each field is occupled by an islet. Beta cells appear dark and other islet cells light. A prominent tissue space separates islets from acinar cells. Formalin fixation. Stained with aldehyde fuchsin and phloxine. $\times 750$.

1 Beta cells may show random placement and constitute slightly over one-balf of the 1slets.

2 Th1s islet is principally composed of beta cells and is typical. A heavy positive stain for beta cells surrounds the capillaries (arrows). 
PLATE I.
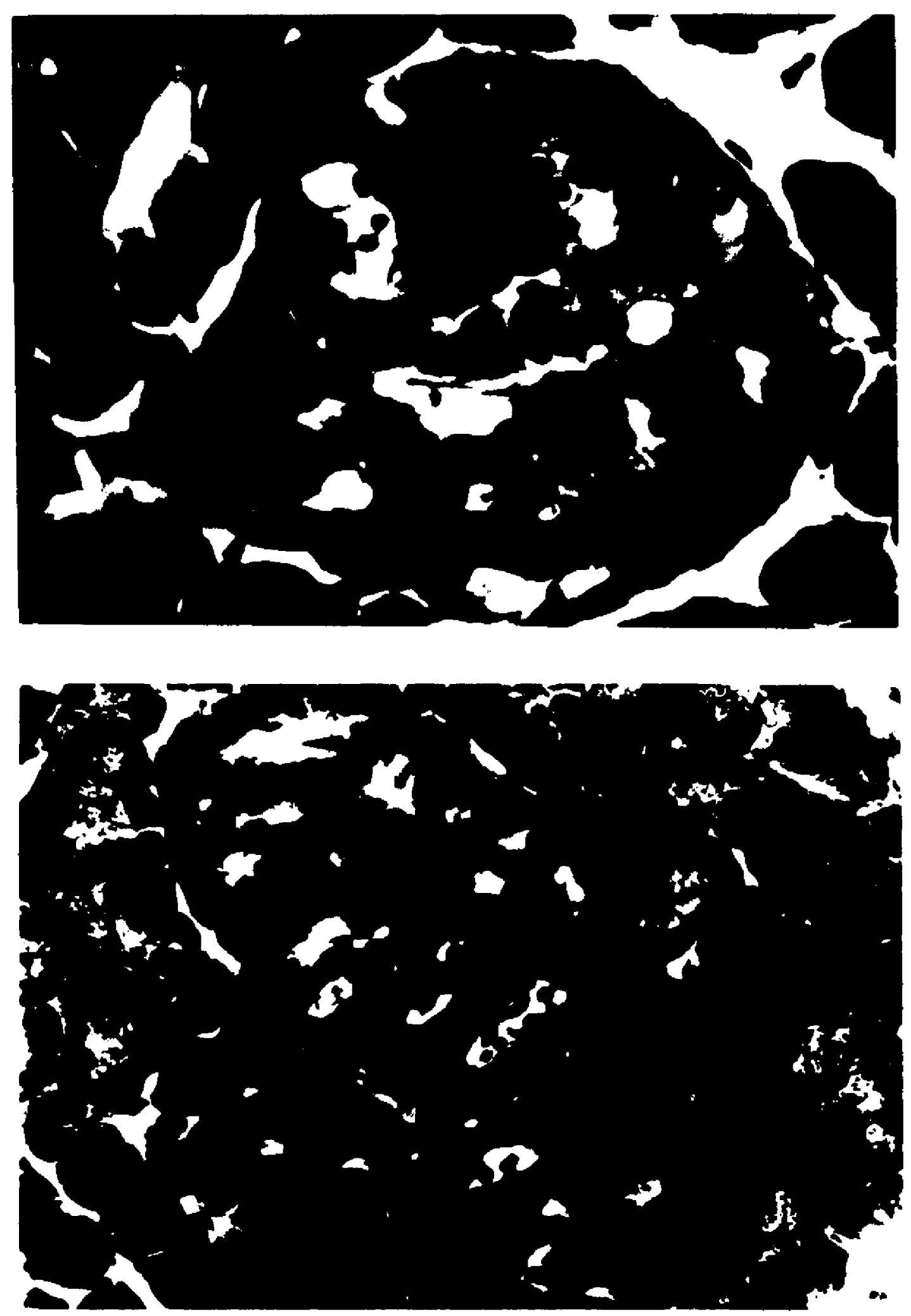
PLATE II.

EXPLANATION OF FIGURES

Maraglas; grids floated on aqueous lead hydroxide for $20 \mathrm{~min}$.

3 The acinar pancreas (AC) is separated from the islet cells by two boundary membranes (BM) which limit the tissue space ( $T$ ). Tro beta cells (B) with finely particulate granules possess lipid droplets (L). Each droplet is surrounded by a dense membrane. An alpha cell (A) with dense homogeneous granules (G) has a prominent Gol\&1 apparatus (GA) containing tmmature granules (arrows). An endothelial cell (EN) of a caplllary borders the lo let. $\mathrm{x} 11,000$.

4 Alpha cells possess dense osmiophilic granules. Each is surrounded by a membranous sac (s). $x 29,000$.

5 Leta cells possess finely particulate granules surrounded by poorly defined sacs (S). A granule with internal porous structure (arrow) is present. $\mathrm{x} 29,000$. 
PLATE II.
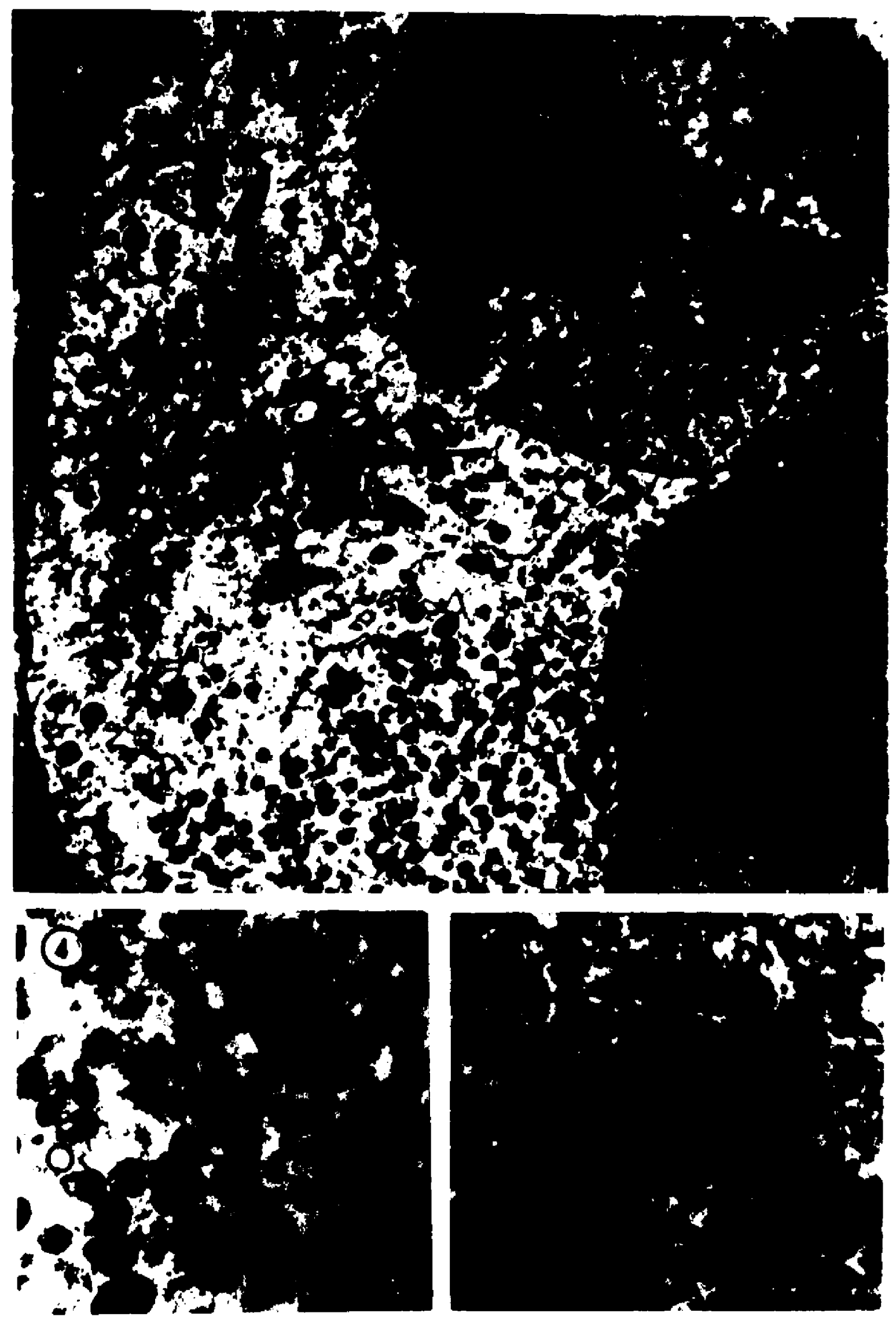
PLATE III.

EXPIANATION OF FIGURE

Vestopal-W; grid immersed in $0.1 \%$ PTA by weight in equal parts of acetone and ether for $30 \mathrm{~min}$.

6 An alpha cell with a lobulated nucleus (NU) is surrounded by three cells; an intergrade (I) with both dense and finely particulate granules, a beta cell (B) with multiple pairs of parallel membranes of granular endoplasmic reticulum (GR) and another beta cell with irregularly shaped mitochondria (M). X12,000. 
PLATE III.

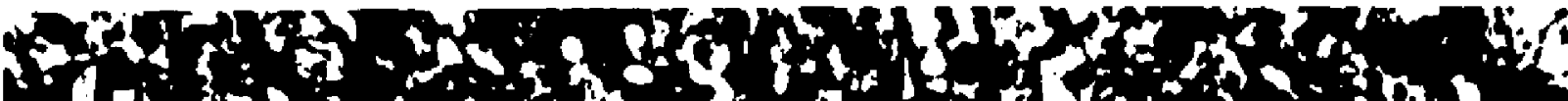

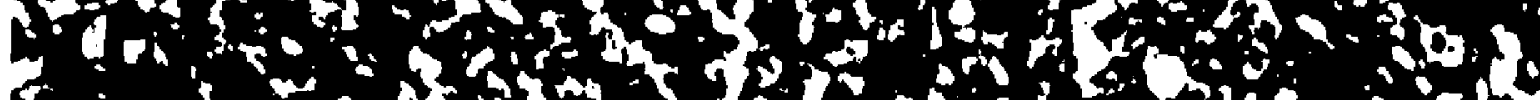

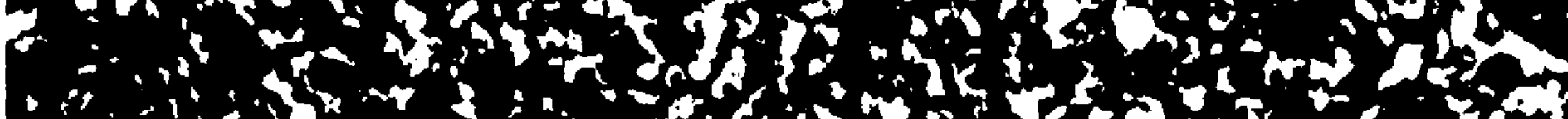

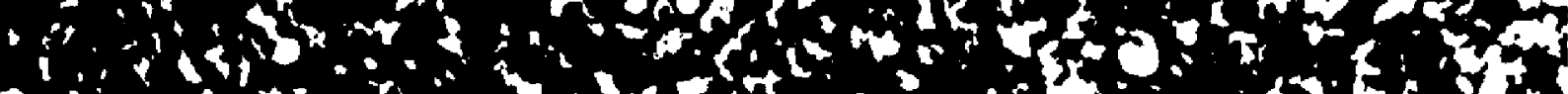

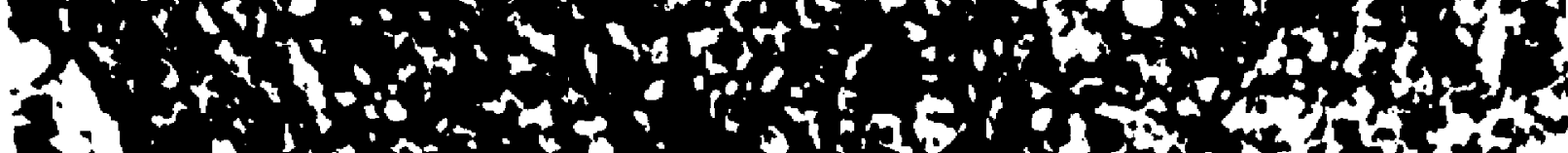

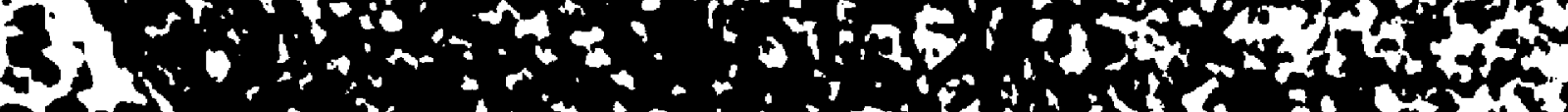
A.

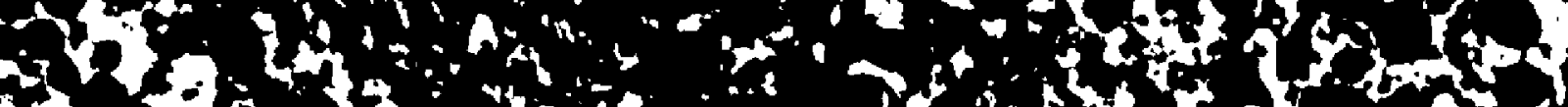

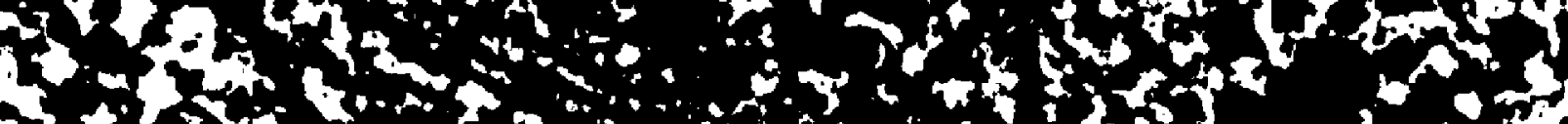

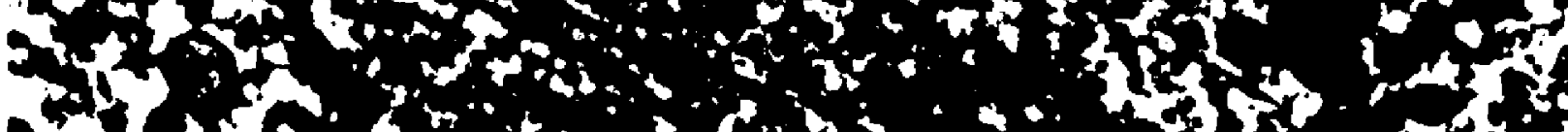

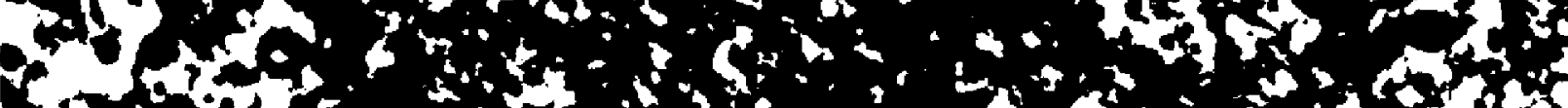

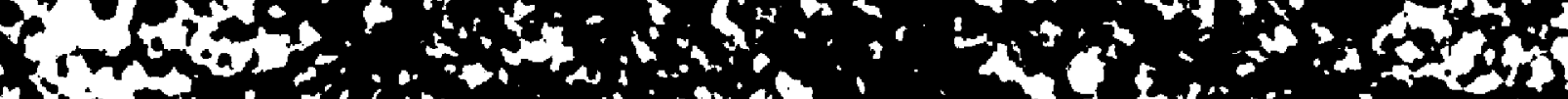

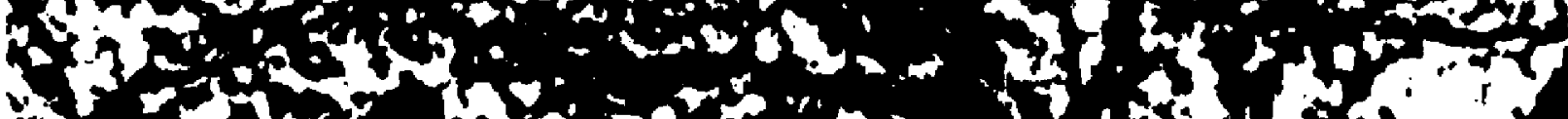

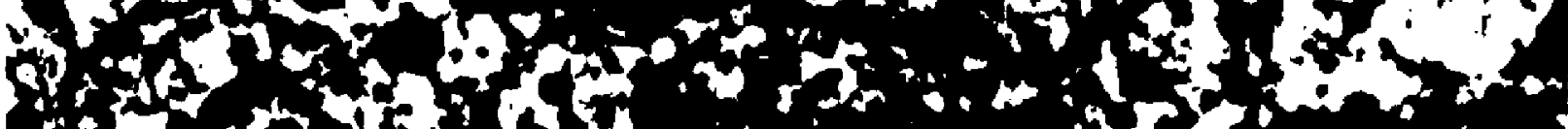

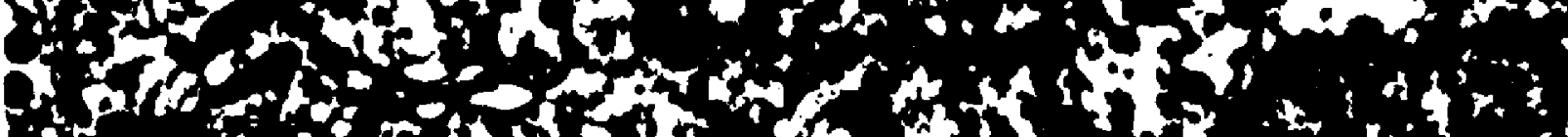

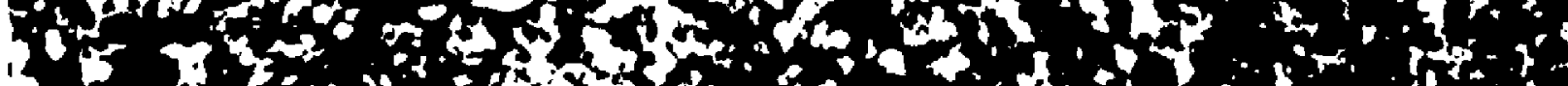

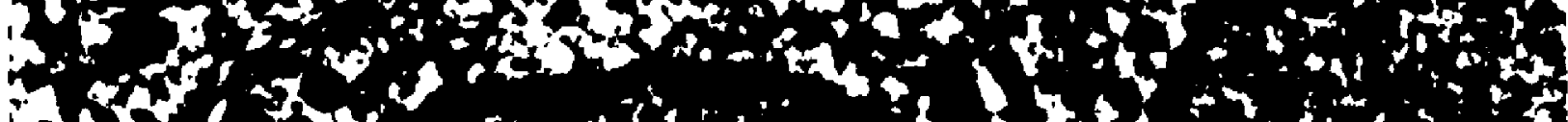

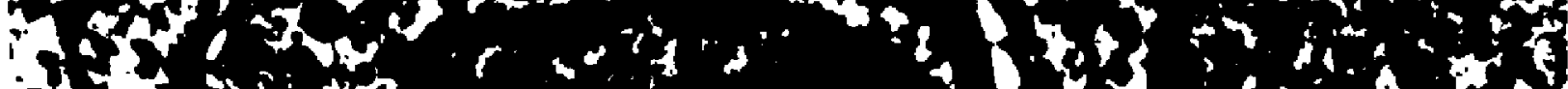

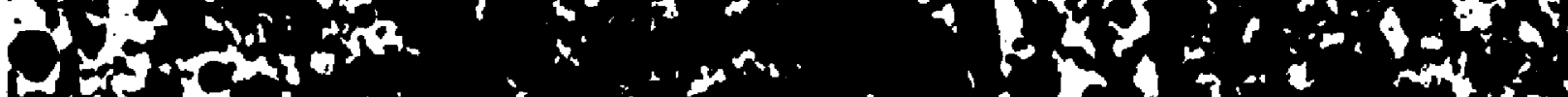

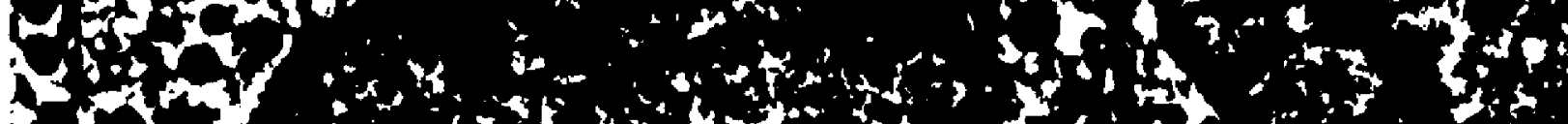

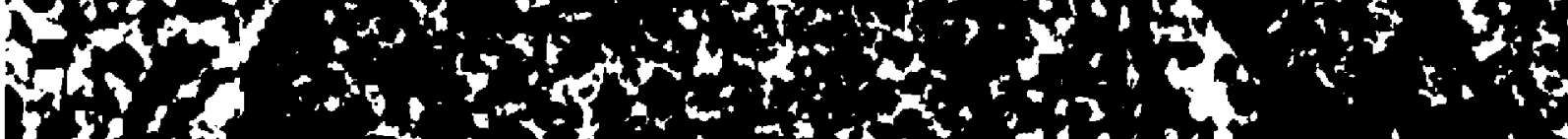

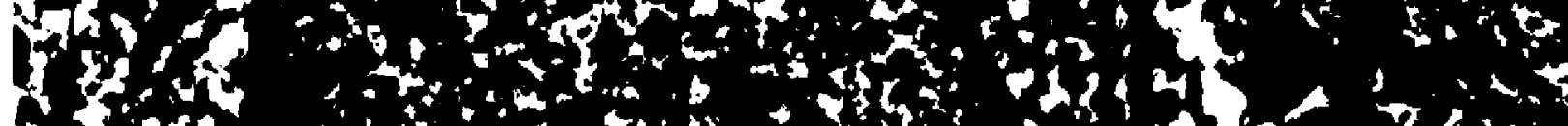

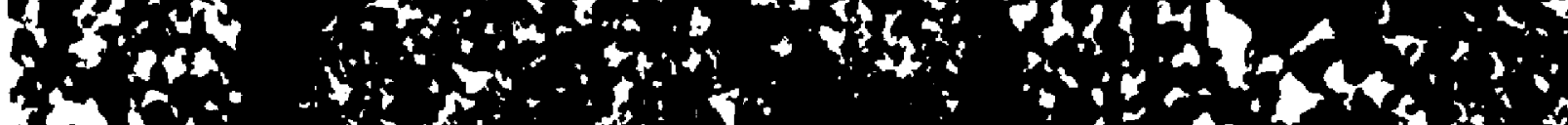
fet

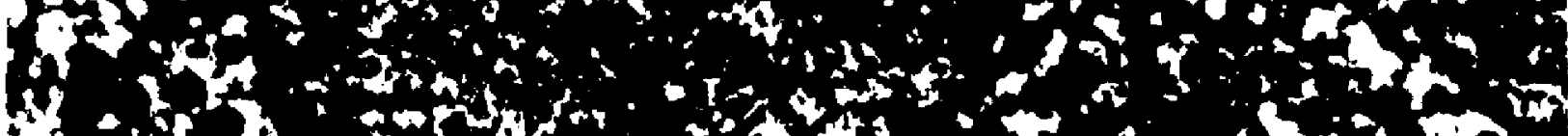

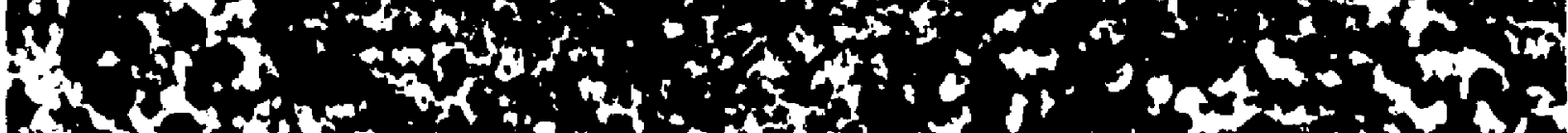

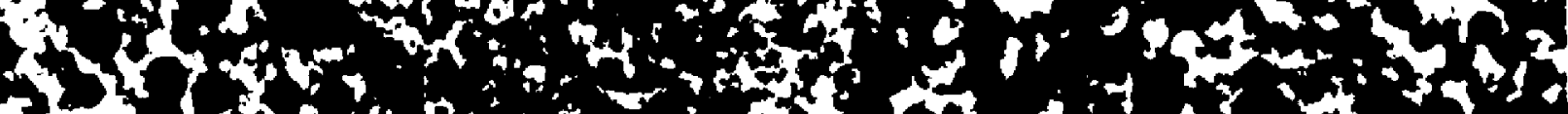

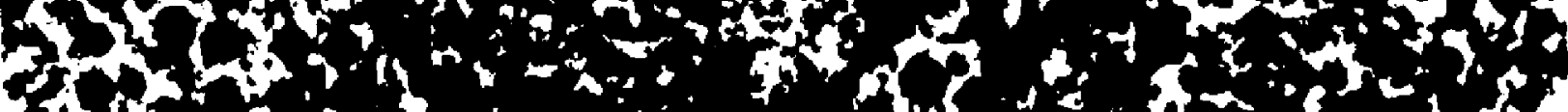

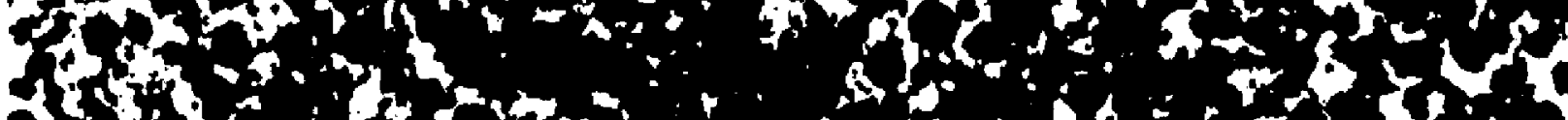

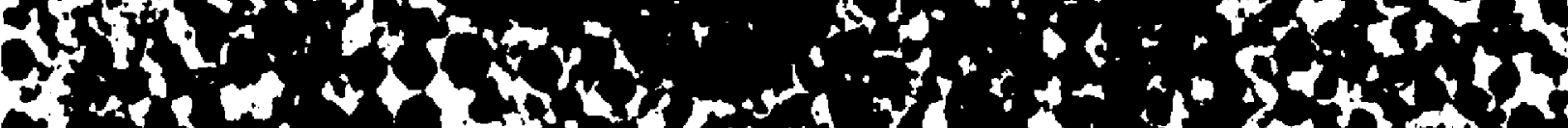

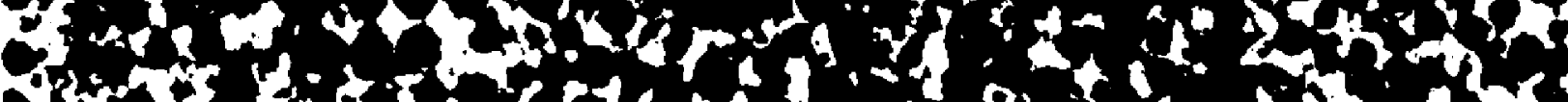

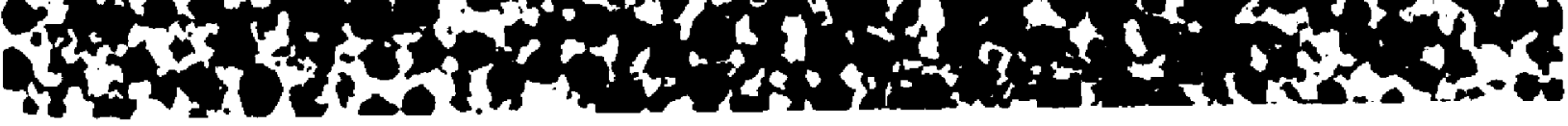


PLATE IV.

EXPIANATION OF FIGURE

Maraglas; grid floated on aqueous lead hydroxide for 20 min.

7 A beta cell (B) with a lipid droplet (L), dilated granular endoplasmic reticulum (GR), agranular endoplasmic reticulum (AG) and a perinuclear cistern in continuity with cytoplasmic membranes (arrows) is adjacent to the acinar cells (AC). Above, another beta cell inveginates a cytoplasmic protuberance $(P)$ into an alphe $\operatorname{cell}(\mathrm{A}) . \times 18,000$. 


\section{PLATE IV.}

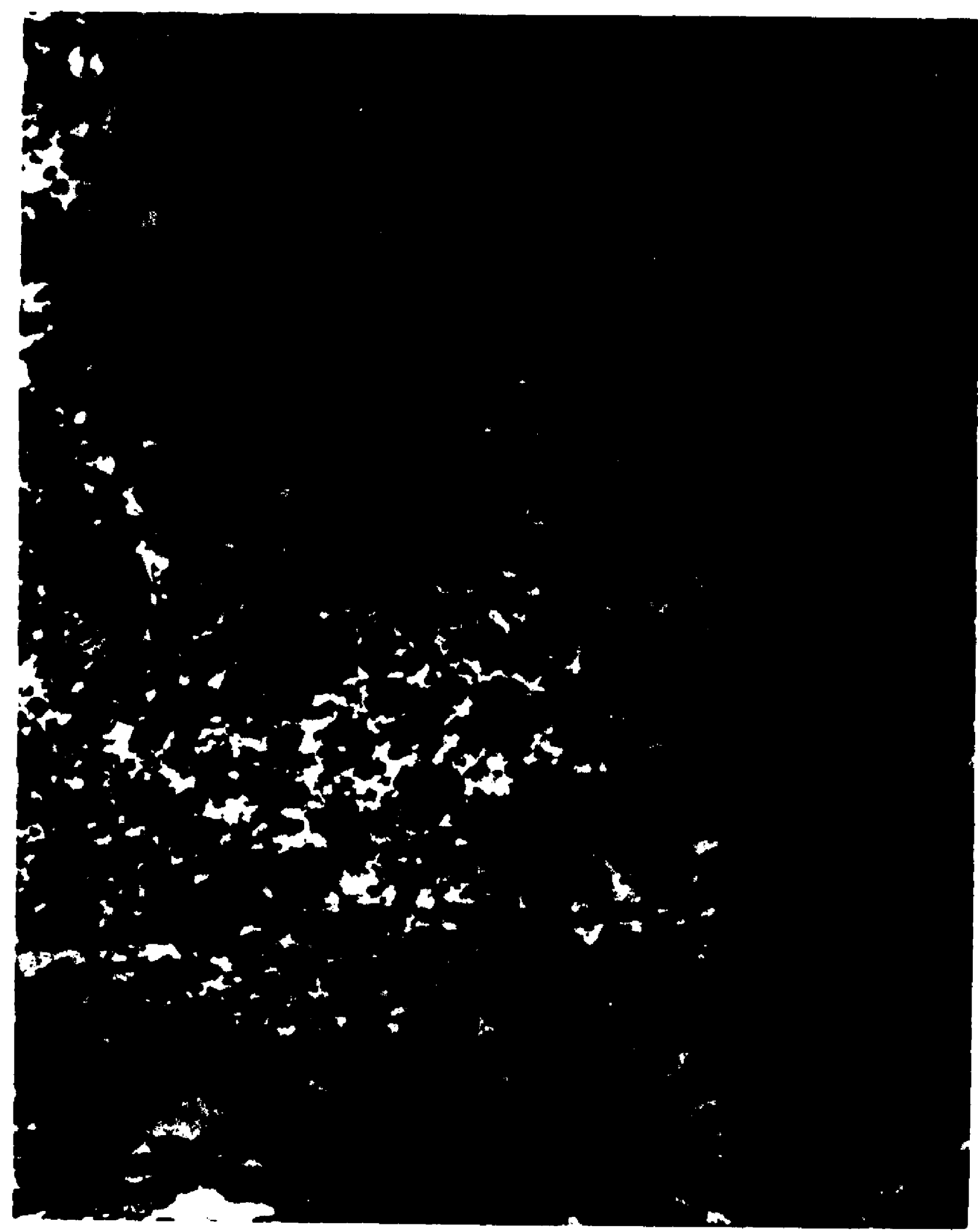




\section{PLATE $V$. \\ EXPLANATION OF FIGURES}

Naraglas; grids floated on aqueous lead hydroxide for $20 \mathrm{~min}$.

8 Elongated mitochondria (M) of alpha cells bave dilated intermembranous spaces (IM). A tangential section of mitochondrial membranes may show "pores" (PO). Clusters of ribosomes (R), dense specific granules and dilated granular endoplasmic reticulum (GR) occur in the cytop?:sm. $\mathrm{x} 41,000$.

9 Oval or rod-shaped mitochondria (M) with irregular outlines are found in beta cells. The Golg1 apparatus (CA) has an immature specific granule (G) associated with it. Ribosomes (R) and dilated cisternae of the granular endoplasmis reticulum (GR) may also be observed. $x 41,000$. 
PLATE V.
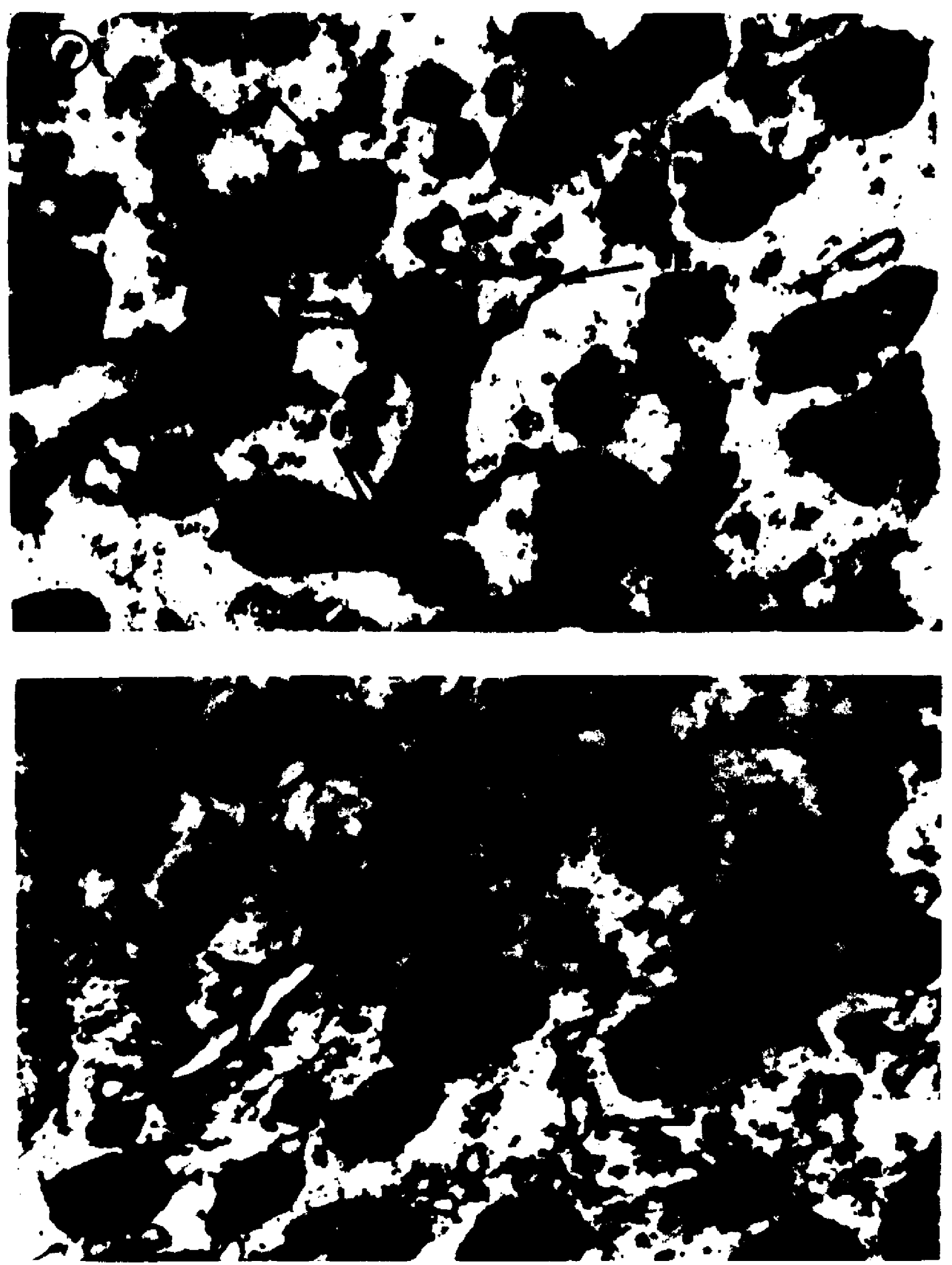
PLATE VI.

EXPLANATION OF FIGURES

Maraglas; grids floated on aqueous lead hydroxide for $20 \mathrm{~min}$.

10 A caplilary showing endothelial fenestrations (FE) borders an alpha cell (A) containing specific granules, three of which are within a single membranous sac (S). A nerve process (N) with symaptic vesicles lies between two alpha cells. $x 23,000$.

11 A delta cell (D) containing numerous empty membranous sacs (S) and a large lipid droplet (L) lies adjacent to two alpha cells (A). $\times 30,000$. 
PLATE VI.

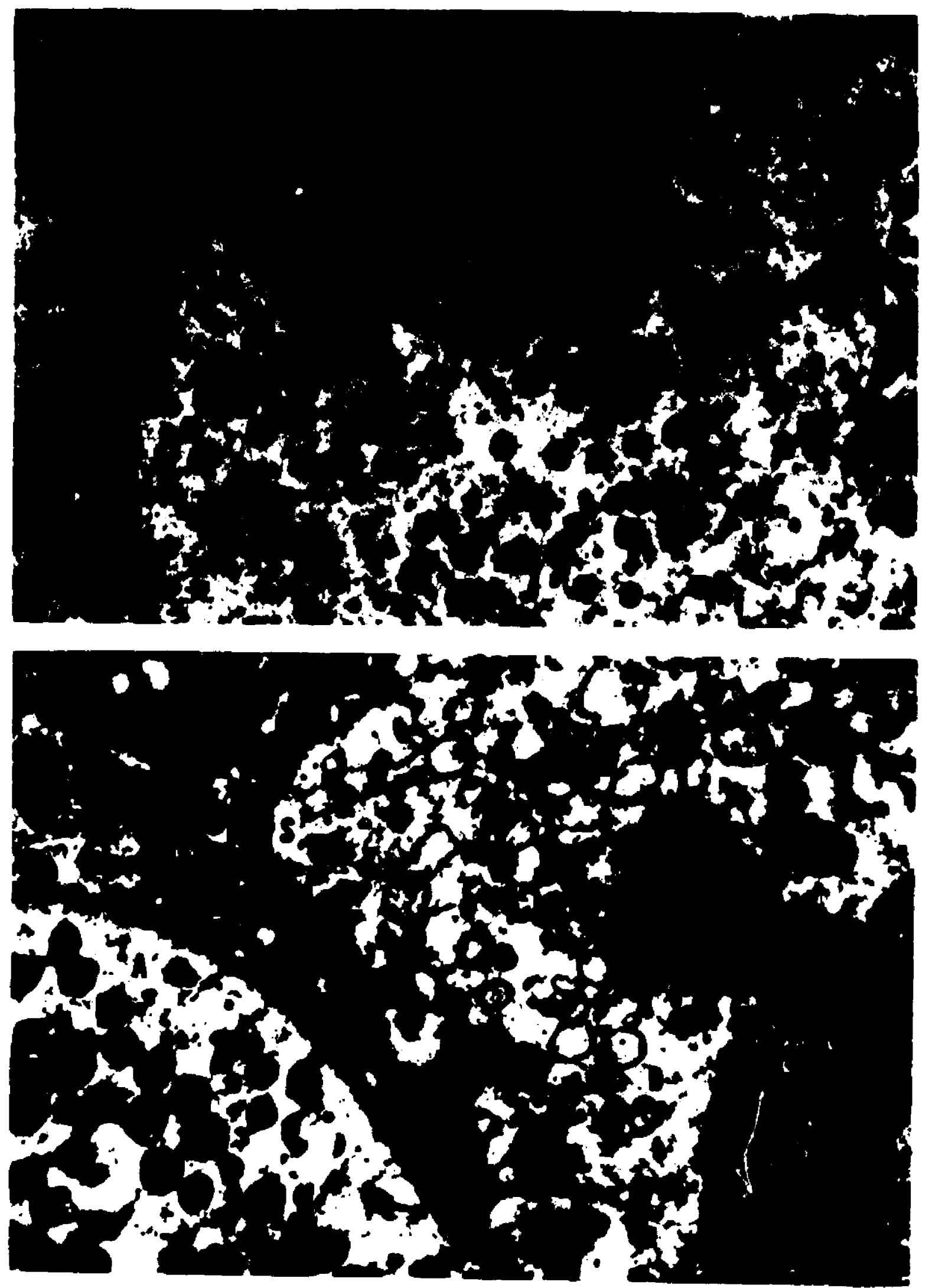




\section{PLATE VII. EXPLANATION OF FIGURES}

12 An 1solated beta cell (B), with specific granules (G), is completely surrounded by acinar cells (AC). A lipid droplet (L) with a circular osmiophosic area appears in the beta cell. Zymogen granules $(Z)$ are present in the acinar cells. Vestopal-W; grid inmersed in $0.1 \%$ PTA by weight in equal parts acetone and ether for $30 \mathrm{~min}$. $\mathrm{x} 10,000$.

13 An 1solated alpha cell (A), characterized by specific granules (G) is surrounded by acinar cells (AC). No connective tisaue stroma Intervenes. Maraglas; grid floated on aqueous lead hydroxide for 20 min. $x 8000$. 
PIATE VII.
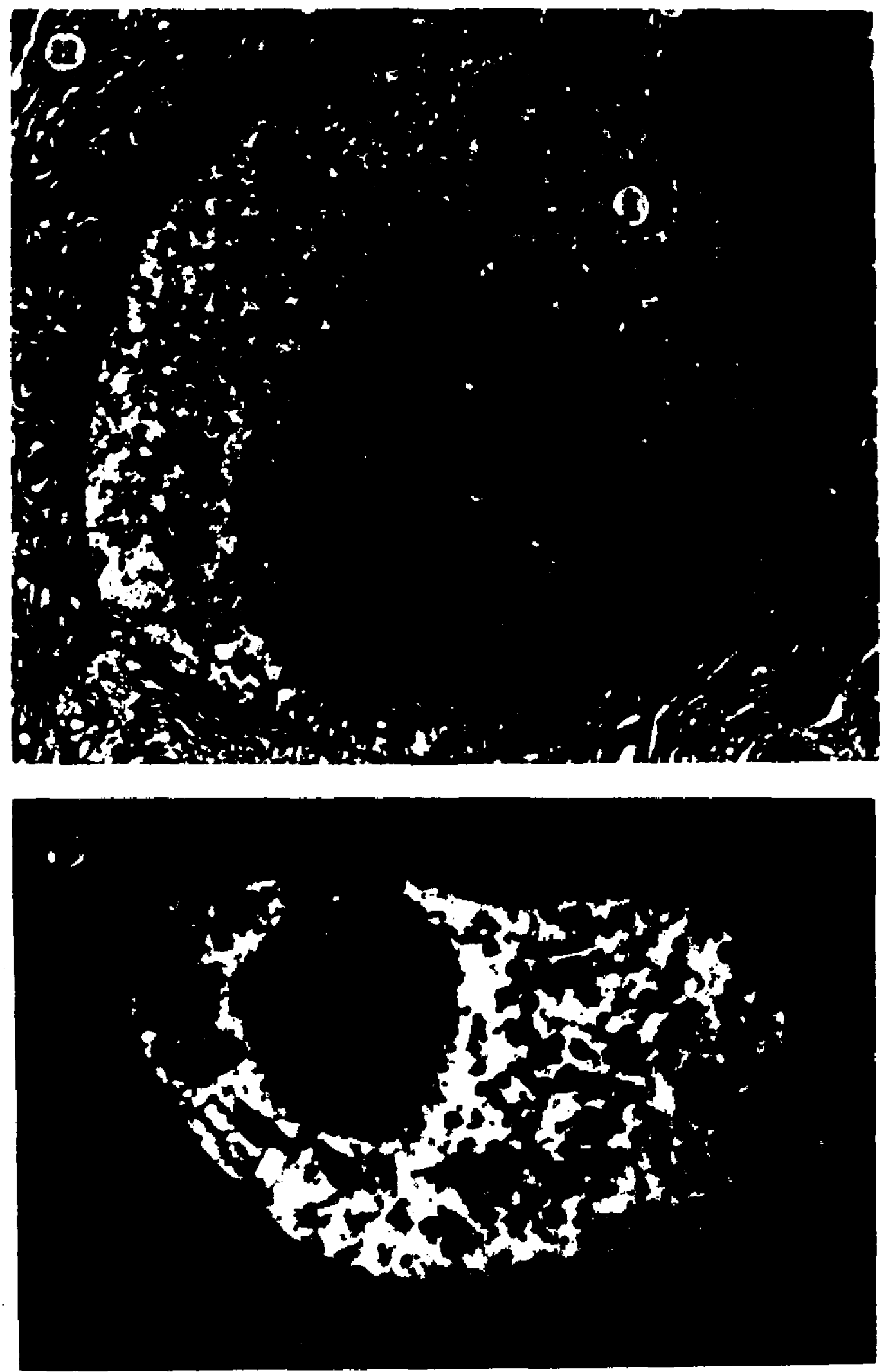
PLATE VIII

EXPLANATION OF FIGURES

Maraglas; grids floated on aqueous lead hydroxide for $20 \mathrm{~min}$.

14 The Golgi apparatus (GA) of this alpha cell contains immature (sraller) speciflc granules (arrows). Mature (larger) granules (G) are also in the fleld. $\times 45,000$.

15 Duct cell mitochondria (M) possess dense intramttochondrial granules (arrows) which are absent in is let cell mitochondria (figs. 8 and 9). The lucid cytoplasm contains only a few membranes of the agranular endoplasmic reticulum (AR) and scattered ribosomes $(\mathrm{R}) . \times 27,000$.

16 Acinar cell mitochondria (M) also possess dense intramitochondrial granules (arrows). The dense cytoplasm has a high concentration of randomly distributed ribosomes $(R)$ and membranes of granular endoplasmic reticusum (GR). X24,000. 
PLATE VIII.

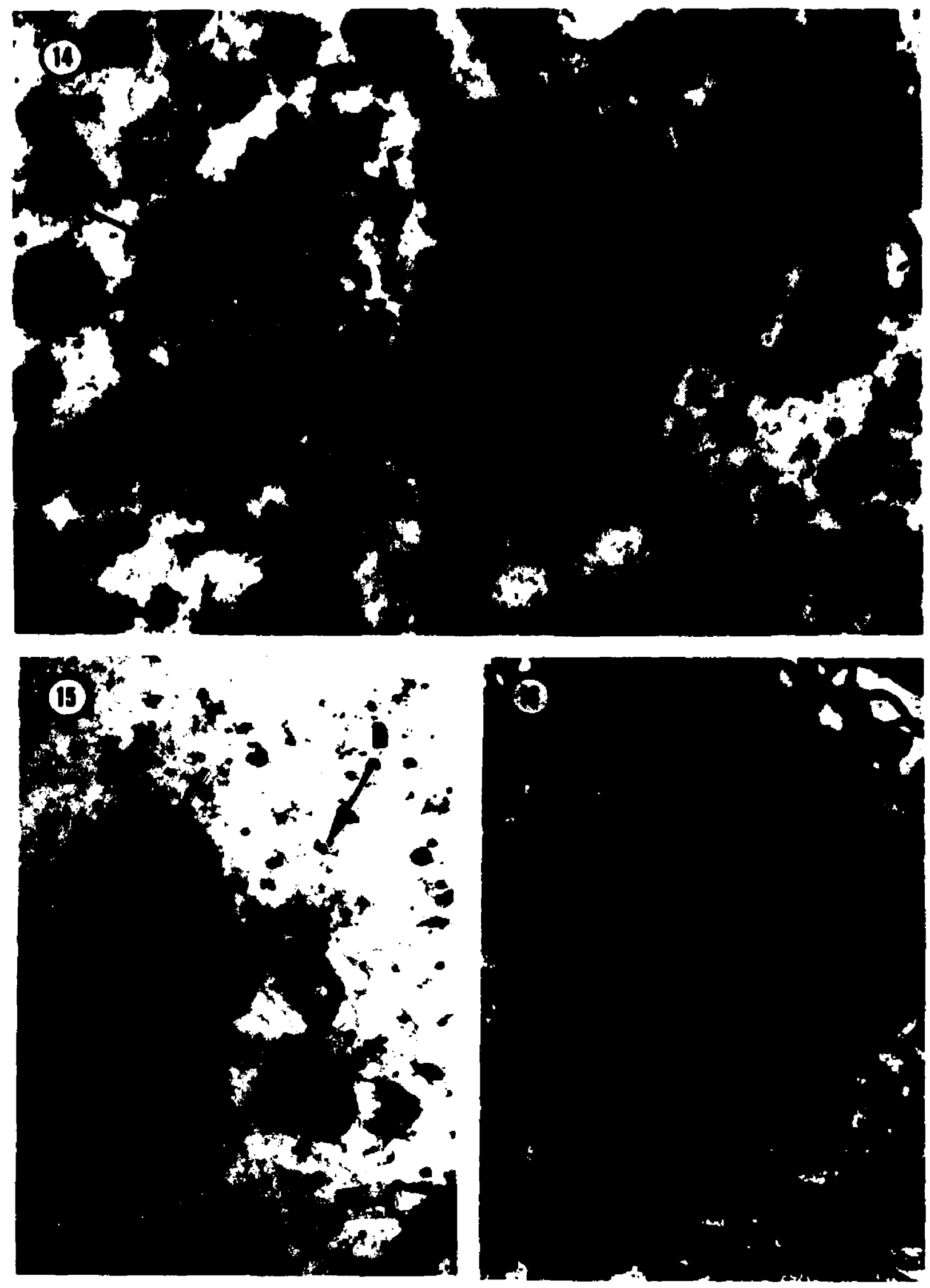


PLATE DX.

\section{EXPIANATION OF FIGURES}

Maraglas; grids floated on aqueous lead hydroxide for $20 \mathrm{~min}$.

17 The cells of small intralobular ducts possess microvilli (MV) and cytoplesmic blebs (CB) projecting into the lumen of the duct. One of the duct cells shows a lipid droplet (L) and others show Interdigitating processess (IP). A typical t1ssue space (T) is Iimited by two boundary membranes (BM) and contalns an unmyelinated nerve (U) and part of a f1broblast (F). X17,000.

18 Duct cells also show desmosomes (DE) and fine cytoplasmic filaments (FI) that appear to converge on longitudinal striations (LS) of a microvillus near the region of the Golgi apparatus (GA). Two other microvilli, cut in different planes of section, display internal structures (arrow). A large cytoplasmic bleb (CB) showIng internal structure is present. $\mathrm{X} 32,000$.

19 A cross-section of one of three microvilli (arrow) shows seven per1pherially arranged annuli and a single central one. $x 54,000$. 
PLATE IX.

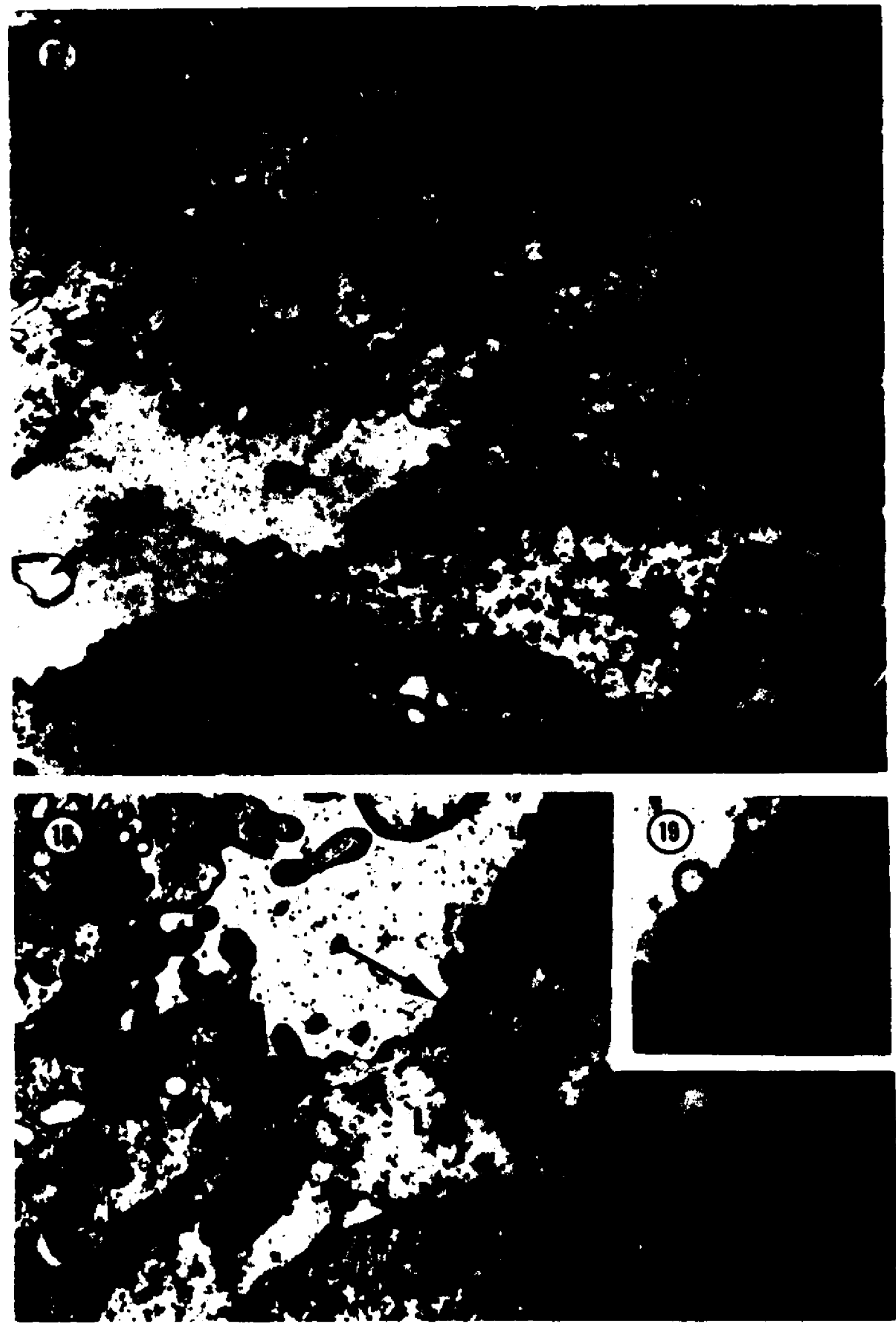


PLATE $X$.

\section{EXPLANATION OF FIGURES}

Maraglas; grids floated on aqueous lead bydroxide for $20 \mathrm{~min}$. These figures show serial sections of nerve processes $\left(\mathrm{N}_{1}\right)$, $\left(\mathrm{N}_{2}\right)$, an encircling cel]. (E) and adjacent alpha (A) and beta (B) ce11s, X17,000.

20 A single nerve process $\left(N_{1}\right)$ shows synaptic vesicles and clusters of mitochondria. An encircling cell (E) surrounds the symaptic process and appears to continue around and make contact with a beta $\operatorname{cell}(\mathrm{B})$.

21 Another nerve process ( $\mathrm{N}_{2}$ ) appears in this field. The encircling cell (E) continues to make contact with the beta cell.

22 The same encircling cell (E), as shown in the above two figures, displays a large and elongated mitochondrion (M). 
PIATE $X$.
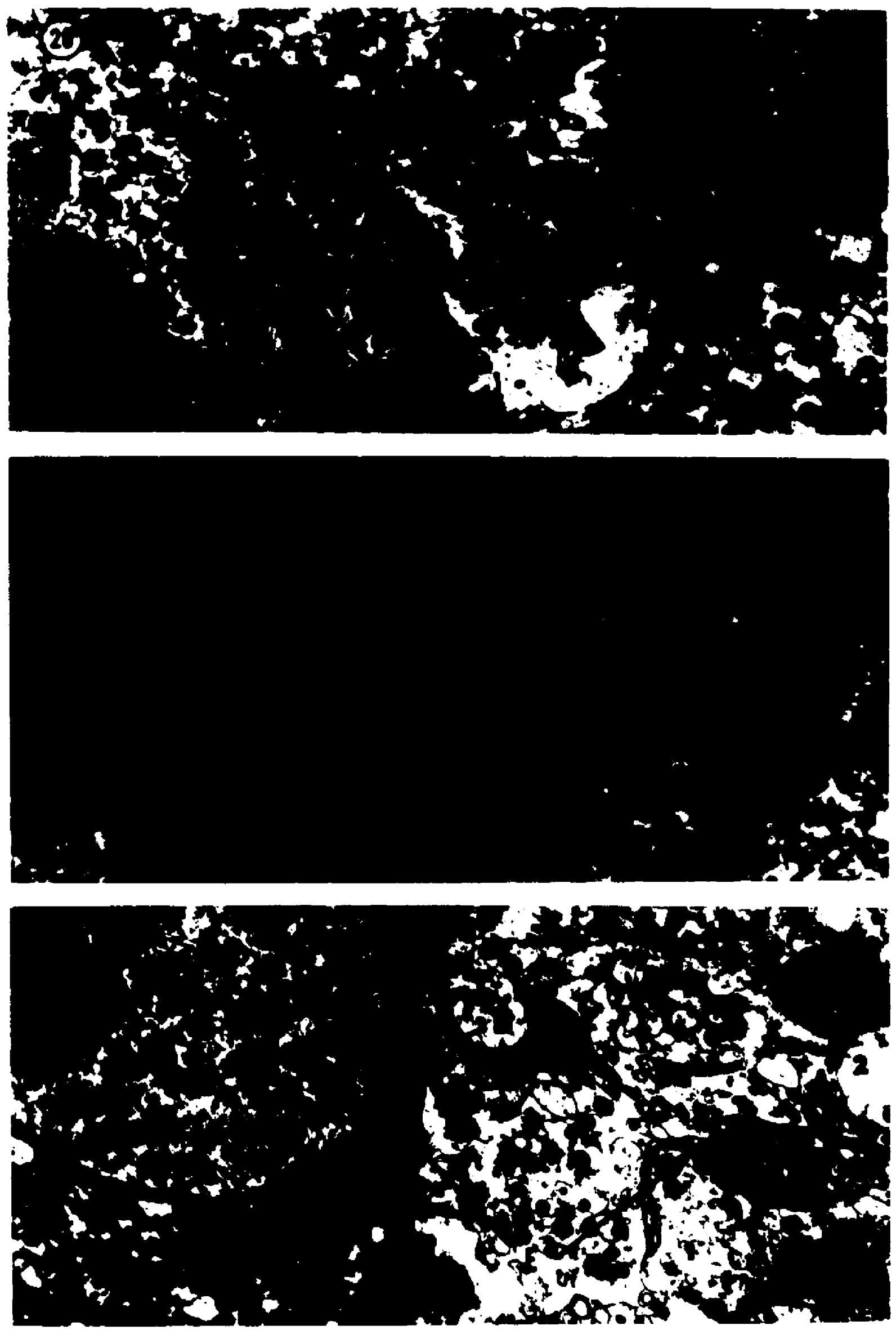


\section{DISCUSSION}

The fine structure of the islets of Langerhans of the Salmiri monkey, as revealed in this study through the use of several new cmbedding media, supports the observations of other investigators (Lacy '57a, b; Bencosme and Pease 158). Islet cells can be distinGuished from acinar and duct cells by the character of the granular endoplasmic reticulum, with nuclear shape and lipid masses also constituting useful criteria. Islet cells themselves are identified by the special morphology of spectflc granules, agranular as well as Eranular reticulum and by their respective cytoplasmlc densities.

'I'he morphology of the alpha cell granules is constant in the doe, rabblt, Guinea pig, rat, (Lacy, 57a, b) bat, (page 497 in Bloom and Fawcett, 162 ) and man (Bencosme et al., 163). They cons1st of intensely osmiophilic spheres loosely enclosed in membranous sacs. Mature cranules, usually found in the vascular pole of the cell (figs. 3,10$)$, are about 2000 A in diameter and of uniform density (fig. 4). Alpha granules in the Golgi apparatus, probably 1mmature (Fawcett, '61), are of the sarne density but are smaller (flgs. 3, 4). The argentaffine cell cranules of the bat stomach, so well 1llustrated by Ito and Winchester ('63) are remarkably similar to these alpha granules but are more than twice the diameter.

Beta granules are as variable in form in the various spectes as the alpha granules are constant. The beta granules of other forms are crystalloid (Lacy '57a, b). In the Salmiri monkey the substance of 
the cranule is finely particldate, being barely resolved in our preparations. 'l'hese particles occupy the entire space enclosed by the sac when the gramules are mature. The granules themselves are about $2500 \mathrm{~A}$ in diameter (figs. 3,9). The crystallold organization typlcal of many other species is not present in the beta granules of this form. Immature granules can be recognized by small size and sparse concentration of the particulate material. They do not always seem to be in the neighborhood of the Golgi apparatus.

Benscome and Pease (158) described delta cells in the cat that possessed "vacuolar compartmentalization" of the cytoplasm. These authors also described a "Branular variant", the granules of which cells possessed Internal structure and were less dense than alpha granules. The vacuolar form was regarded as typical. A more recent study (Bencosme et al., (3) also favored this interpretation and it was postulated that delta cells might represent immature beta cells. In our materlal delta cells of the vacuolar variety are present (fig. ll), but whether or not they represent immature forms is not clear. 'The possibility that the vacuoles might represent regressive changes should not be 1gnored.

I'hree islet cell types: alpha, beta and delta can be identifled as indicated above, by their specific granulation (or lack of 1t). These three types account for most of the islet cells but not for all of them. The term "intergr'ade" (Winborn, '62) is useful to deslgnate the few cells that possess both high density (alpha) and low density (beta) granules ( $f i g .6$ ). These intergrades might correspond to the cells seen in light microscopy that are on the borderline between one type and another. The $\mathrm{C}$ cells described by Lacy in the guinea pig pancreas are not present in our material. The cells of small ducts often resemble them. 
The nuclel of 1slet cells in this study are consistently irregular in outline (figs. 3, 6, 7), being similar to those observed in dog islets (Lacy, 157). The fibrillar structures in the nucle1 of human islet cells described by Bencosme et al. (163) are also present, althouch rare, in both islet and acinar cells. "lhe nuclear envelope (fie. 7) resembles the perinuclear cistern of watson ("35) more than the classic douhle memhrane system of lartmann ('53). Immature specifle Granules are sometines associated with the Golci apparatus (rics. 3, 9,14 ) possibly indicating the site of synthesis (Fawcett, '61; Ferreira, 157). This is conspicuous in alpha cells but inmature beta Erandles are less frequently observed in the same place. According to experiments with tolbutamide, the Golei apparatus in beta cells is not involved in insulth fomation (Lacy 1). In surmary, the Golei apparatis seems to play a dominant part in Eranule formation in alpha cells but beta cells moie closely simulate the mode of synthesis des-

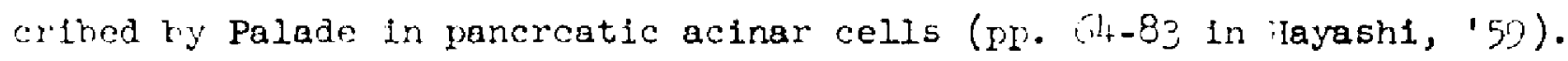
Mituchondria were described by kunger ("58) in the mouse as rodshaped in both alpha and beta cells, the hicher concentration being in the latter. A similar gencralization can be made from this study except that leta cell mitochondria tend to be oval with irregular outlines (fiE. 9). They closely resemble those with dilated intermembranous spaces, as described by Andrea (12) in the developine spermatocyte. The intramitochondrial granules which are so consplcuous in acinar and duct cells (fiEs. 15, 16) are absent in all 1slet cells, both in the monkey and in other animals.

Conspicuous lipid droplets are present in the islets of tho human pancreas (Bencosme et al. 'ú3). Similar structures have been found in 
this study, but are limited larely to the beta and delta cells ( $\Gamma$ igs. $3,7,11,12)$. Many of these droplets closely resemble the homogeneous varicty described in interstitial cells by Fawcett and Bureos ("5i). These author's make note of the prominence of slmflar 11pid droplets in steruid-productide irlands. Lipld masses have been described in dogs (Lacy, '170) but do not appear to be as prominent as those of human and monkey islets.

Cytoplasmic density differs markedy between alpha and beta cells. It is expressed chiefly $b_{y}^{\prime}$ the Eranular und agranular endoplasmic reticulum, isslated $r i b$ somes and the lemainder by the cytuplasmic matlix as defined by Polter (Trachet and Mirsky, 'ul). ilowever, a finer structure in the matrix has been described (Battie and Low, 'il; Battie and Clevencer, 'Ul), the ir.egular tubulo-membranous component (IIM). Ihis latter system appears to be contributory to the different densities between alpha and beta cells.

Single or isolated tslet cells ( $\Gamma$ iEs. 12, 13) are more conspicuous In electron microscopy than those seen with the light microscope. Ihey have little tendency toward lobulation of the nucleus and concentration of specific cranules. 'lhe boundary between these isolated cells and the acinar pancreas is not marked by the presence of intervening connective tissue, there beine direct apposition of the plasma membranes of the islet and acinar cells. Cunticuous membranes occasionally Interdicitate. Small croups of islets may be simllarly related ty acina* cells. If the islets are separated from the acini by an appreciable distance, then connective tissue is present.

Certain portions of the duct system (figs. 17, 18) are included in this report because the individual cells closely resemble islet 
cells. However, the absence of specific cranules identifies these cells as part of a duct system. Tubules, apparently the anastomosing ones of light microscopy (page 501 in Bloom and Fawcett, '62), are present throughout the monkey pancreas. Some of these tubules connect to islet cell masses. Rarely, single islet cells form part of this system, which is said to consist of undfferentlated epthelium. Lipld masses are present in the duct cells (fig. 17), and there is apparently no difference between these droplets and those of islet cells. Cytoplasmic blebs and mierovilli (figk. 17, 18) were shown in the duct system of the rat pancreas by Ekholm et al. ('62). In the centroacinar and Intercalary ducts these aththors demonstrated annuli in cross-sections of the microvill1 and interpreted them as longitudinally arranged cylinders cut in section. Microvilli with the same arrangement of annuli, seven peripheral and one central (fig. 19), are als present in the Saimiri monkey. Longitudinal striations appear in the microvilil ( $\mathrm{flg}$. 18), not only beyond the free surface of the cell, but sometimes extending within it near to the Golgi zone. The cytoplasmic filaments associated with microvill1 (f1g. 18) are comparable to structures of the cell web described by Leblond et al. $(+6)$.

The nerve fibers present in the monkey islets contain synaptic vesicles (figs. 20, 21, 22), which, accordinf to De Robertis ('61), are almost exclusively confined to the presynaptic site. Many of them resemble the nerve endings in the central nervous system (Palay, '56) and at the myoneural junction (Palade, 154). The processes observed in this study do not have the localized thickenings of the cell membranes characterlstic of other synaptic sites. What is referred to 
as enclrcline cell (figs. 20, 21, 22) always intervened between islet and nerve process. The 1dentity of this cell is not known, and it does not correspond to any lslet cell type ubserved in this study. A connective tissue stroma is recognized to be closely assoclated with the islet cells in light microscopy. :iere, a reticulum more or less delimits islets from acint (pace lyj in Bloom and Fawcett, '62) and accompanies blood vessels. In electron microscopy this reticulum shows various units of organization and this warrants reinterpretation. The simplest expression of the stroma is seen where there is a small but apparent space between islet and acinar cells. llere, boundary (basement) membranes (Low, 'jla) follow both islet and acinar cell plasma membranes (fic. 3). The tissue space intervenes. other formed elements of the connective tissue such as fibroblasts and/ or unit flbers of collacen, may appear between the two boundary membranes in the tissue space as seen between duct and acinar cells (fig. 1'). These elements, beine part of the connective tissue, lack boundary membranes of their own. It is clear that the connective tissue stroma of the pancreas, where it forms the reticulum of $11_{\text {int }}$ nicroscopy, exemplifies an ulrastructural pattern found generally throughout the body. 'This pattern, recognized in electron microscopy although largely uniformulated (Pease, 198; Policard and Collet, 150) was described in the alveolar wall by Low ('ila) in terms applicable to the entire body. The descriptive term "boundary nembrane" designates the membranous formed element determining the extent of the tissue space. Battie and Low (161) later presented an analysis of connective tissue ultrastructure in the heart, where the boundary membrane concept was used to help identify certain cell types. Dougherty's descriptions 
If the cervical uterine mucosa ("ia, b) interpreted the connective tissue accordine to the sjstematics of this boundary membrane concept, and confilmed the presence of the same pattern in the uterus. In the monkey pancreas this ultrastructural situation is present. It is typical and without variation. 


\section{LITERATURE CIIED}

André, Jean 1962 Modification ultrastructurales du chrondriome.

J. Ultrastruct. Res., (suppl.) 3:1-55.

Batt18, C. G., and M. R. Clevenger 1961 An Irregular tubulo-membranous component (ITM) of protoplasm. Anat. Rec., 139: 328.

Batti8, C. G., and F. N. Low 1961 The ultrastructure of buman cardiac mascle and 1ts assoclated t1ssue space. Am. J. Anat., 108: 199-230. Bencosme, S. A., R. A. Allen and H. Latta 1963 Functioning pancreatic is let cell tumors studied electron microscopically. Am. J. Path., 42: $1-22$.

Bencosme, S.A., and D. C. Pease 1958 Electron microscopy of pancreat1c islets. Endocrin., 63: 1-13.

Bloom, W., and D. W. Fewcett 1962 A Textbook of Histology, 8th ed. W. B. Seunders Co., Philadelphia. Brachet, J., and A. E. Mrsky 2961 The Cell. Academic Press, New York, 2: $621-675$.

Dalton, A. J. 1951 Electron mlcrography of ep1thelial cells of the gastrointestinal tract and pancreas. Am. J. Anat., 89: 109-133. DeRobert18, E. 1961 H1stophysiologische Aspekte die S1gnalübermittlung Im Nervensystem die Rolle der symaptischen Bläschen. Triangel, 5: $76-89$.

Dougherty, C. M. 19628 Relationship of normal cells to t1saue space In uterine cervix. Amer. J. Obstet. Gynec., 84: 648-656. 
1962b Extrecellular relationships in normal and malignant epithelial cells of the uterine cervix. Obstet. Gynec. (NY), $19: 592-617$.

Ekholm, R., T. Zelander and Y. Edlund 1962 The ultrastructural organtzation of the rat exocrine pancreas. I. Acinar cells, II. Centroacinar cells, intercalary and intralobular ducts. J. Ultrastruct. Res., 7:61-72, 73-83.

Farqubar, M. G. 1961 Fine structure and function in capillaries of anterlor pltuitary gland. Ang10logy, 12: 270-292.

Fawcett, D. W., and M. H. Burgos 1956 Observations on the cytomorphosis of the germinal and Interstitial cells of the buman test18. Cibe Foundation Colloquia on Ageing, 2: 86-99.

Ferre1ra, D. 1957 L'ultrastructure des cellules du pancréas endocrine chez l'embryon et rat nouveau-né. J. Ultrastruct. Res., 1: 14-25. Freeman, J.A., and B. O. Spurlock 1962 A new epoxy embedment for electron microscopy. J. Cell Biol., 12: $437-443$.

Comori, G. 1939 A differential stain for cell types in the pancreatic 1slets. Am. J. Path., 15: 497-500.

1950 Aldehyde-fuchsin: A new stain for elastic tissue. Am. J. Clin. Path., 20: 665-666.

Hartmann, J. F. 1953 An electron optical study of sections of the central nervous system. J. Comparat. Neurol., 99: 201-249. Hayash1, T. 1959 Subcellular particles. The Roland Press Co., New York.

Ito, S., and R. J. Wincuester 1963 The fine structure of the gestric mucosa in the bat. J. Cell B10l., 16: 541-577. 
Lacy, P. E. 1957a Electron microscopic identification of different cell types in the 1slets of Langerhans of the guinea pig, rat, rabb1t and dog. Anat. Rec., 128: 255-267.

$1957 \mathrm{~b}$ Electron microscopy of the normal islets of

Langerhans. Dlabetes, $6: 498-507$.

1961 Electron microscopy of the beta cell of the pancreas. Am. J. Med., 31: 851-859.

Lacy, P. E., and W. S. Hartroft 1959 Electron microscopy of the lislets of Langerhans. Ann. N. Y. Acad. Sci., 82: 287-300.

Lacy, P. E. and J. R. Willianson 1960 Electron microscopic and fluorescent antibody studies of islet cell adenomas. Anat. Rec., (abstract) 136: 227-228.

Leblond, C. P., H. Puchtler and Y. Clemont 1960 Structures corresponding to terminal bars and terminal web in many types of cells. Nature, 186: 784-788.

Low, F.N. 196la The extracellular portion of the human blood-air barrler and 1ts relation to t18sue space. Anat. Rec., 139: 105-124. $1961 \mathrm{~b}$ Methods of clearing t1ssue sections embedded in Vestopal-W. Proc. European Reglonal Conference on Electron Microscopy, Delft, 1960, 2: 615-618.

Low, F. N. and M. R. Clevenger 1962 Polyester-methacrylate embedments for electron microscopy. J. Cell Biol., 12: 615-621.

Luft, J. H. 1956 Permanganate - a new fixative for electron microscopy. J. Blophys. Biochem. Cytol., 2: 799-802. Millonis, G. 1961 A modified procedure for lead staining of thin sections. J. Blophys. Biochem. Cytol., 11: 736-739. 
Munger, B. L. 1958 A light and electron microscoplc study of a cellular differentiation in the pancreatic islet cells of the mouse. Am. J. Anat., 103: 275-312.

Palade, G. E. 195? A study of fixation for electron microscopy. J. Exp. Med., 95: 285-298.

1954 Electron microscopic observations of interneuronal

and neuromuscular synapses. Anat. Rec., 118: 335.

Palay, S. L. 1956 Symapses in the central nervous system. J. Biophys. B1ochem. Cytol., 2: 193-202.

Pease, D. C. 1960 The basement membrane: substratum of histological order and complexity. Fourth Int. Conf. on Electron Microscopy, Berlin, 1958. 노 139-158.

Policard, A., and A. Collet 1959 Les membranes basales et leurs roles dan la physiologie normale et pathologique des tissus. Rev. Franc. Etudes Clin. Biol., 4 : 283-289.

Rhodin, J. A. G. 1962 The diaphragm of caplllary endothelial fenestrations. J. Ultrastruct. Res., 6: 171-185.

Robertion, J.S. 1954 A morphological study w1th the electron microscope of sections of the normal pancreas. Aust. J. Exp. B1ol. Med. Sc1., 32: 229-234.

Ryter, A., and E. E. Kellenberger 1958 L'Inclusion au polyester pour l'ultramicrotomie. J. Ultrastruct. Res., 2: 200-214. Spurlock, B. O., C.V. Kattine and J.A. Freeman 1963 Modifications in Maraglas embedding techniques. $J$. Cell Biol., (in press). Watson, M. L. 1955 The nuclear envelope: Its structure and relation to cytoplasmic membranes. J. B1ophys. Blochem. Cytol., 1: 257-270. 
Williamson, J.R., and P. E. Lacy 1959 Electron microscopy of islet cells in alloxan-treated rabbits. Arch. Path., 67: 102-109. Winborn, W. B. 1962 Electron micrographs of the islets of Langerhans of the monkey pancreas. Anat. Rec., 142: 345-346. 


\section{BIOGRAPHY}

W11liam B. Winborn was born in Victoria, Texas on October 6, 1931. He graduated from Patt1 Welder High School in V1ctoria, Texas in 1950. Shortly thereafter Mr. Winborn entered the U. S. Marines, serving on active duty from 1950 to 1951. Following bis honorable discharge from the military service, he entered college in 1952 and graduated in 1956 with a bachelor of Sclence degree from the University of Texas. He entered the Graduate School of Loulsiana State UnIversity in 1958 and is now a candidate for the degree of Doctor of Philosophy in the Department of Anatomy of the School of Medicine, in New Orleans. 


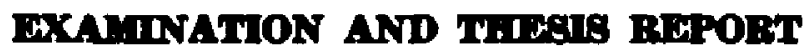

Candidate: William Burt Winborn

Major Field: Anatomy

Title of Thesis: Light and Electron Microscopy of the Islets of Langerhans of the Sainirt Monkey Pancreas.

Approved:
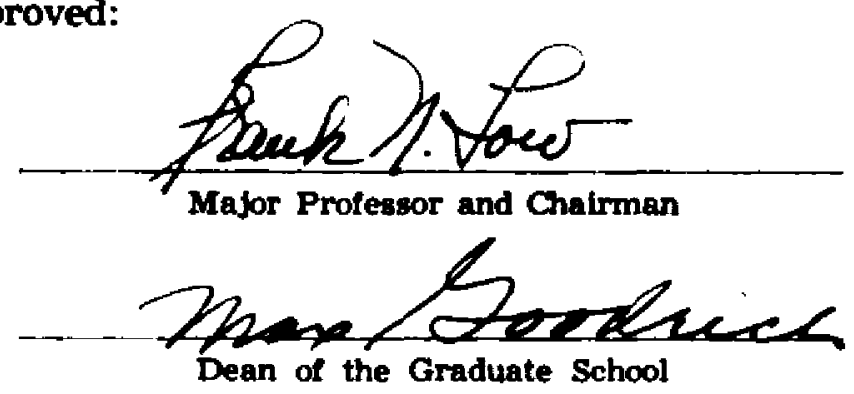

EXAMINING COMMITTEE:
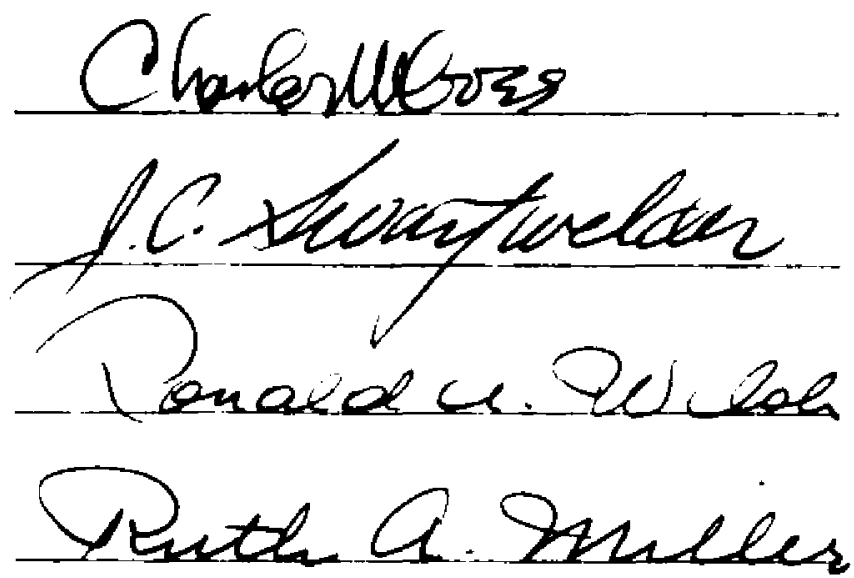

serge helen Poudrow

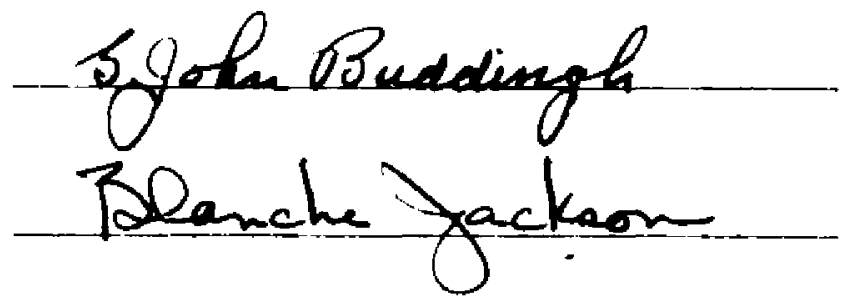

April 29, 1963 